\title{
The Courts, the Qadi, and the 'People': Resolving Mercantile Disputes in the Medieval Islamic Mediterranean
}

\author{
Jessica Goldberg
}

The Cairo Geniza contains very few records of lawsuits between Jewish merchants in the eleventh and twelfth centuries. And by very few, I mean there is only solid evidence of five such full-blown mercantile lawsuits coming before the Jewish court in the period 990-1150. Such a small number of cases is perhaps surprising - letters, the main source of information we have from merchants represented in the Geniza, are replete with disputes in need of resolution. It is all the more interesting because we know that Jews in major cities and some smaller towns throughout Fatimid and Ayyubid Egypt and Syria maintained local communal courts that oversaw, ratified, and recorded transactions, agreements, and arguments among Jews (they did not handle crossconfessional cases): sales, gifts, loans, commercial contracts and disputes, and those related to marriage, divorce, and inheritance. Indeed, the plurality of materials from the documentary Geniza are legal.

I want to unpack the possible meanings of the paucity of mercantile lawsuits in the light of recent scholarship from a number of fields. Such research helps to better contextualize this fact, and then use this context to help reassess explanations other scholars have offered as to the small volume of suits. I will then propose some alternative explanations where I try and place mercantile dispute processing into the context of both the commercial practice and recent research in medieval Islamic law. ${ }^{1}$

1 At the suggestion of the editors, this piece represents a lightly revised version of the plenary talk for the conference, with limited citations and a selected bibliography. I am grateful to Louis Sicking for helping me be part of the proceedings, and to Eve Krakowski, Marina Rustow and Oded Zinger for their help with the content. Their willingness to share their research in progress, and to discuss both theory and practice of law in the Geniza, have enriched my understanding of the subject at every turn. 
I have now mentioned two terms of art: the Cairo Geniza, and the documentary Geniza. An explanation is in order. Between the eleventh and the nineteenth centuries, Jews attached to the oldest synagogue of Fustat, Egypt (the commercial sister-city of the royal Cairo, founded by the Fatimids in 969 and in the eleventh and twelfth centuries still largely a court enclave), like Jews as well as Muslims elsewhere in the Middle East, intermittently practiced geniza, a ritual disposal of worn-out and useless religious texts. The synagogue (now called Ben Ezra) holds a special place in the heart of historians because the community it served used a small chamber in the building as a permanent geniza, rather than a box or some other form of temporary storage that would periodically be buried. The collection of writings (on paper and parchment, handwritten or printed) that accumulated over nine centuries, now known as the 'Cairo Geniza', was discovered by European and American scholars in the late nineteenth century. Egypt's semi-colonial status, the complex question of the 'ownership' of the materials, and scholarly and collecting practices of the day means contents of the Cairo Geniza are now scattered across some seventy libraries and private collections in Europe and the United States.

Forms of geniza practice varied not only within and among communities, but also over time, with some periods during which the Ben Ezra Geniza was in use seeing significant deposits of non-sacred material. Most of the Geniza papers - about 380,00o folio pages in all - are fragments of literary manuscripts, largely on religious subjects. But somewhere between fifteen- and thirty-thousand pieces of paper contain what is usually termed documentary material; that is, they are everyday writings, texts written not to convey ideas to an anonymous and long-lasting audience but to communicate with specific recipients for immediate practical purposes. The largest and best-studied cluster of these everyday writings - perhaps as many as thirty thousand texts dates back to the Fatimid and Ayyubid era $\left(969-125^{0}\right){ }^{2}$ These kinds of everyday

2 The difference between fragment, document, and text helps explain these numbers. A fragment is an individual piece of paper extant in the Geniza. A document is a coherent piece of written composition - a letter, an entry in a legal register, a petition. A text is any part of a document found on any particular piece of paper. Since paper was valuable in the classical period under discussion, it was often re-used. Thus a piece of paper may contain more than one document. Equally, some documents were lengthy, using more than one sheet of paper (if they were not the kind of document that required a long scroll or rotulus). Finally, in their time in the Geniza storeroom, many sheets of paper were torn, meaning that even something like a letter, generally written on only one sheet of paper, might need to be reassembled virtually, some several pieces of paper, perhaps housed on different continents. 
writings, from this era of dense deposit, are called the documentary Geniza. It is one of the largest groups of everyday writing to have survived from the medieval Islamic world, and perhaps the single densest and most diverse. It contains at least fifteen sub-corpora of identifiable types of writing with more than a hundred exemplars (and for a handful, thousands of exemplars) records of court hearings, marriage contracts, pre-nuptial agreements and deeds of divorce, contracts and deeds involving property and commerce, learned answers to legal questions, magical amulets and recipes, commercial correspondence, family correspondence, communal correspondence, medical prescriptions, commercial accounts, accounts of communal property and charitable aid management, private petitions from the poor, petitions to state authorities and records of the Fatimid and Ayyubid governments. ${ }^{3}$

Many of the documentary Geniza's diverse sub-corpora of documentary types, moreover, are closely interconnected and illuminate some of the same people, practices, places, events, and institutions from multiple angles. For example (and not unrelated to my discussion), scholars have identified around two thousand documents produced by or for merchants who participated in the great markets for wholesaling primary production and manufacturing across the eastern Mediterranean and western Indian Ocean. The largest group is letters exchanged among merchants and business accounts, but it also comprises business ephemera (drafts and preparatory material for letters, shipping notes, office lists, orders of payment) and various materials pertaining to family affairs, communal activities, or scholarly pursuits, as well as a small smattering of legal materials (contracts, powers of attorney, settlements, lawsuits, wills - in no case more than a half-dozen). As many of these men formed a loose but identifiable group of individuals and families, we can trace their activities across several generations, from around the year 990 to the mid-twelfth century.

The relatively small number of scholars capable of handling the linguistic and paleographic challenges of the material, and the dispersal of the materials, long delayed progress in assessing the corpus in its entirety. But in the past decade and a half, an increasing pace of digitization has helped a growing number of specialists make more sense of contents, leading to a greater awareness not only that legal documents (court hearings, deeds, contracts, settlements,

3 The broad range of document types that provide an almost unimaginable treasure trove for social historians. Individually, these documents are often surprisingly detailed and varied as well as relatively well preserved, especially compared to pre-Islamic papyri. The corpus as a whole offers some of the best evidence we possess not only of the social, cultural, and economic history of Jews in the medieval Islamic world but also of the social and economic history of the pre-Ottoman Middle East in general. 
quittances, and wills) are the plurality, but that more than half the materials of the documentary Geniza touch on the workings of the economy, the state, and the law. Of the legal documents themselves, most are records of hearings of the Rabbinic court. Not all of the court's business was lawsuits, nor even most of it: people also went to the Rabbinic court to have all sorts of agreements properly witnessed (one might best conceive of a combination notary office and court). But there are hundreds of records of lawsuits - meaning that the five lawsuits among living merchants makes them account for an exiguous part of the court's business. There is thus an apparent disjuncture - a set of materials full of people going to court, and almost as full of merchant materials, but with modest overlap between the two.

Contracts and Contract Enforcement: Jewish Law in a Muslim Milieu

Two different understandings of contract creation and enforcement among these Jews have been offered that could explain what seems to be an underrepresentation of lawsuits among merchants. S.D. Goitein proposed that Jewish merchants would have gone to Muslim courts, whose records are not extant; Avner Greif proposed that the courts were economically useless and contract enforcement was achieved without recourse to it. Both men's work has great value in recognizing important problems of mercantile practice and evidence, but I will suggest reasons why neither model really accords with the larger world of Geniza evidence that is currently emerging, and then present the legal, normative, and evidentiary context that I think better explains the nature of dispute resolution for the merchants.

S.D. Goitein, who pioneered the study of these merchants and their business methods in the 1950s and 1960s, proposed something like a divide between the public and private lives of Jews in the Islamicate Mediterranean. In matters of family, marriage, and religious devotion, he believed we should expect Jews to follow particularistic Jewish practices, developing norms out of their ancient written tradition. In the ecumenical marketplaces, neighborhoods, and even public spaces of the large courtyard houses that Jews often shared with Muslims or Christians, however, Jews could not have been that much different from their neighbors. In the particular case of merchants, he thought that they went to Muslim notaries to register their contracts so that they could be used in the markets. If, as he suggests, their contracts were written to conform to Islamic rather than Jewish law, the solution could be that merchants went to Muslim courts to settle their disputes even when the 
disputes were between fellow Jews. Such materials would not have ended up in the Geniza, which generally does not contain any legal evidence from the Muslim courts.

Could Goitein be right, that the relative absence of litigation is an illusion of source bias? In general, the Geniza records attest broadly to the possibility of 'forum shopping' by litigants; that is, it was possible, even in a dispute between two Jews, to bring a case before a Muslim judge. ${ }^{4}$ Both the Fatimids and Ayyubids ruled their empires according to a model of judiciary established by the Abbasids, which permitted religious courts run by and for non-Muslims to operate alongside Islamic judges (qadis). These courts operated in the shadow of the state's own system of legal tribunals, through which any subject, whether Muslim or non-Muslim, could present appeals (mazālim, literally ‘[complaints against] abuses') directly to the government. In the slow evolution of the relationship between state and court in the Islamic Mediterranean, the first stateappointed qadi in Egypt was installed in the 77os by the Abbasid caliph alManșūr; a century later, ibn Ṭūlūn began accepting mazālim petitions directly from his subjects - a key part of his assertion of independence, despite being nominally the Abbasid governor. The Fatimids absorbed and expanded both institutions, allowing qādīis of diverse legal affiliation to operate under the authority of a formally Isma'illi chief judge (qāộ̀ al-qudāt) while also responding to complaints and requests filed through an elaborated system of mazälim petitions.

As my colleague Oded Zinger has shown, in certain kinds of cases litigants in Jewish courts would threaten to take a case to Muslim court. This was a particularly common strategy for women in inheritance disputes (daughters have universally enshrined rights to a share of the property in Islamic law but not in Jewish), but is also quite frequent in marriage disputes. Jewish litigants sometimes brought cases to the Muslim court by common agreement, and some business contracts (though none among the merchants we are considering) state that cases of dispute will be brought before the Muslim authorities if they fail to find an agreement in the Jewish court.

There is in addition scattered evidence from the Geniza more generally of Jews acquiring 'Arabic legal documents' (presumably from Muslim courts) for agreements with fellow Jews: of fathers having property deeds drawn up by the Muslim courts in order to pass property to their daughters, or of partners in a

4 Not only was this possible between a Jewish and Muslim court, one could also choose between qadi or mazälim court, but most often, it was Muslim litigants who strategically choose from among different qadis. 
shop bringing their Arabic partnership deed to the Jewish court in order to dissolve the partnership.

There are also a few bits of evidence that seem at first to support the idea that these Jewish merchants made agreements in Muslim forums. First, we find several incidents recounted in letters in which merchants called upon a qadi to intervene in a commercial dispute. Second, there is the evidence of a pair of contracts read into evidence in the Rabbinic court in the settlement of a case in which a merchant died en route to Sicily, and the elders of the community of Tripoli took possession of the goods he was carrying. The first contract attested that the goods were held in partnership between the deceased, a Sicilian, and his partner in Cairo. The goods were also labeled as belonging to the deceased. The second contract, contradicting the first, asserted that the goods were entirely the property of the merchant in Cairo. The court testimony records that the first contract had been written in order to evade excessive customs' duties then being imposed on 'foreigners' goods (indeed, some mercantile letters show that this ruse became so general that the Sicilian authorities escalated and charged the due on all goods, and then as suddenly gave up the scheme).

But on closer examination, none of these materials actually provides good evidence that Jewish merchants registered their agreements with Muslim notaries or took their disputes to Muslim courts to settle them. Certainly, the first contract regarding goods had been made to show Muslim authorities. Unfortunately, we do not possess the original contracts, only the records in JudeoArabic that they were read into evidence (as in many modern courts, documents must be read into evidence in order to become part of the suit - we have records of more contacts in this form than we have originals). ${ }^{5}$ But nothing about the first contract actually suggests it was drawn up by Muslim notary - it does not follow the language of Islamic formularies. ${ }^{6}$ Rather, it was composed according to norms we are just now beginning to recognize as a Jewish scribal legalese that emerged in the eleventh century, just like the second contract. Equally, the incidents in which a qadi is brought into a dispute between Jewish merchants, it is in order to take an executive action to sequester goods in dispute, not to actually rule on the merits of the case. Though an outsider might think that use of the Hebrew script would have made Jewish legal documents

5 Like many kinds of legal documents that might have an important afterlife for an individual or family, most originals were not deposited in the Geniza.

6 In the absence of a large number of contemporary contract edited from the papyri collections, it is not clear whether Muslims in Egypt would have adhered closely to such formularies at the time. 
useless to non-Jews, Geniza evidence shows that individuals of the time were under no such illusions - when they wanted to keep something secret, they would write key terms (such as illicit items of trade or even terms for the officials they were afraid of) in the Hebrew language.

Rather, several strands of evidence suggest that Jewish merchants considered the Jewish courts the natural forum for pursuing lawsuits if they arose. The evidence of the extant lawsuits shows, naturally, the possibility of pursuing a commercial case in the Jewish courts. Though in principle they cannot tell us anything about the frequency of going to the Muslim courts as a court of first resort, it is interesting and important to note that in none of the cases do the litigants threaten to appeal to the Muslim court. (In the case with the longest paper trail in the Geniza, the court itself has the litigants promise not to pursue the matter in the Muslim courts, though the case had dragged on for months).

But rather better evidence for merchant practice is found in the letters. Though there are no mentions, interestingly, of active lawsuits in these, there are a substantial number of discussions of recourse to legal measures - of taking oaths, raising the possibility of issuing a power of attorney, discussion of sending powers of attorney, actual inclusion of powers of attorney, discussions of the consequences of issuing a power of attorney, threats (always made to third parties, never directly to one's opponent) to sue, appeals to legal experts for issuance of opinions, and many discussions of 'the people' that is, the community of merchants, attempting to resolve matters. Such mentions occur in more than ten percent of letters. And wherever the evidence is not ambiguous (as, alas, in the nature of letters, it very often is), the evidence points to the Jewish courts and Jewish legal experts when the dispute is among Jewish merchants. Thus, for instance, when we hear that a power of attorney was issued in Fustat against a merchant in Qayrawan, the merchant in Qayrawan goes to the Jewish judge to get assurance that the case will go his way if it proceeds, letting us know that the forum is the Jewish court. Similarly, in several cases where legal opinions are sought from experts, they are Jewish experts.

More in-depth study of the legal materials of the Geniza, as well as more research into the day-to-day nature of Jewish leadership in local communities at first deepen the mystery of why anyone would go to a Jewish court, and then helps explain why we might expect Jewish merchants to handle their affairs largely within the ambit or shadow of the Jewish court. First, as first discussed by my colleague Marina Rustow and then confirmed by several recent Ph.D. dissertations, we must understand the Jewish court not as part of a Jewish communal sphere that acted autonomously from the Islamic state and legal system (a very old vision of Jewish autonomy that the most recent generation 
of Geniza scholars has been at great pains to lay to rest), but as deeply embedded within it. Indeed, Jewish courts were considered a part of the state's judicial system and Jewish judges would, like qadis, receive deeds of appointment from the Muslim authorities.

By the same token, a great deal of research has also uncovered the rather severe limits on the enforcement capacity of the courts. That is, for most of the period documented in the Geniza, its officials lacked any real coercive power. ${ }^{7}$ A few Geniza documents from the early eleventh century mention rabbinic judges sentencing Jews to flogging for specifically religious offences (e.g., keeping a shop open on the Sabbath), but none make clear whether the floggings were to be administered by agents of the Jewish community or of the state, or indeed whether they actually occurred at all. ${ }^{8}$ After this, references to corporal punishments imposed directly by court officials disappear from the Geniza record; Jewish litigants appear to have been physically punished only by turning them over to the state for judgment. Short of this, rabbinic courts had three means of suasion at their disposal: they could require litigants to swear oaths of varying religious weight, fine them for legal infractions or for breach of contract, or excommunicate them, a form of social ban that theoretically prevented them from interacting with other Jews. The documents also suggest that only the Muslim or mazälim courts could imprison defendants for failure to appear (and did so imprison Jewish defendants).

The impositions of the Jewish court are not necessarily trivial sanctions. But surviving documents suggest that in practice, all three were limited coercive tools. Fear of lying under oath might encourage a litigant's cooperation when he was in the courtroom, but could not ensure that he would show up there in the first place, nor obey officials' orders after he left. The fines stipulated in Geniza documents can be remarkably large, but this mattered little if there was no way to force litigants to pay them; in fact, all available evidence indicates that they were routinely renegotiated and rarely, if ever, paid in full.

7 I should note that $q \bar{a}$ dịs did not maintain their own police force either, and were subordinate

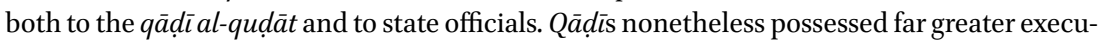
tive power than did the bet din, not only because some controlled armed guards, but also because they possessed much closer ties to state officials and often worked together with them to administer physical punishments and to confiscate goods.

8 Taylor-Schechter Genizah Collection, Cambridge University, Cambridge (hereafter T-S) 8J7.18 (written by Efrayim b. Shemarya, about a Sabbath-violating shopkeeper), T-S 18J1 r. 6 (1028, Cairo, about a ritual slaughterer accused of malpractice), T-S 13J33 r. 4 (about a cantor accused of slandering a communal official). 
Excommunication, the most severe punishment that the court could apply, bore theoretically drastic personal and economic consequences. But it was nearly impossible to implement perfectly - Geniza evidence for people isolated by the ban is remarkably thin on the ground - a shortcoming that meant it was thus best imposed infrequently, lest its overuse damage court officials' own credibility.

Jewish courts thus lacked effective means to enforce judgments or the terms of contracts that they had issued, or even to compel litigants to appear before them in the first place. Yet the same record that reveals this fact also demonstrates that they remained robust and well-patronized institutions throughout the Fatimid and Ayyubid periods. Even without any tangible mechanisms forcing them to do so, many Jews went to considerable expense to negotiate interpersonal conflicts and document their transactions in rabbinic court. But, as my colleague Eve Krakowski astutely analyzes and documents in her work, Geniza scholars have also misunderstood some of the complex cultural constructions of law in Islamicate societies in their thinking about the possibilities of forum shopping and the limits of practical enforcement capacity as limiting the appeal of courts. A central source of Rabbinic courts power was their claim to specialized legal knowledge of a kind that carried cultural weight throughout Fatimid and Ayyubid Egypt, and beyond - among not only Jews and other dhimmiss, but also the Muslims who ruled over them.

As Krakowski explains, the Islamic societies that emerged out of the Abbasid empire (750-945) shared certain common social and political assumptions, among them a notion of social order embodied by law. Religious law (sharia) meant normative rules derived from written prescriptive texts that dictated both ritual and social behavior, to be administered in religious courts that commanded both sacred and civil respect. But such ideas did not just apply to Muslims: those following other legitimate religious traditions, dhimmiss, should possess their own characteristic bodies of religious law. This stance, as shown in the texts they wrote under the successor regimes from the tenth through fifteenth century, shaped Jewish and Christian leaders' own self-presentation. Jewish and Christian texts indeed show Muslim rulers must have valued dhimmī loyalty to their own legal tradition; accusing a fellow Jew or Christian of being untrue to their own law (engaging in bid'a, the term in Islamic law for innovation) could be a successful strategy for gaining Islamic rulers' sympathies. Thus, though naïve piety has been rightly seen as an inadequate explanation for why dhimmis should go to their own courts, in a milieu where the idea of religious law was both widely recognized and taken seriously, the practical legitimacy and power of the rabbinic courts could indeed be a serious matter 
for Jews. ${ }^{9}$ Their own claims to standing as subjects worthy of state protection were bound up, at least in part, to their adherence to dhimmi shari'a.

Geniza research in the past two decades, moreover, has shown that Goitein's imagined separation of spheres - economic life lived according to Islamic norms, and family and marriage according to Jewish - signally fails to emerge in practice. Several recent studies of court production around family, gender and marriage has shown the degree to which Jewish families used the courts to ratify arrangements that conformed much more closely to Islamic law than that found in Talmudic texts, and also find the court working to avoid outcomes that were acceptable by Talmudic precept, like child marriage, but did not accord with Islamic norms of family in the Fatimid period.

If we turn then to the merchants in particular, their position in the community did everything to confirm that adherence to the Jewish legal arena would have been important to them, while at the same time making the Jewish courts the most practical place to rehearse disputes. Geniza merchants were usually among the leaders of their local Jewish community, part of the circles who supported the community financially and pursued prestige through scholarship both in youth and in adulthood. Many were not merely knowledgeable in law, but were experts nearly on par with the scholars - in one case at least, a scholar capable of writing responsa himself. In the Jewish courts, then, they were in a position of considerable power. The Jewish courts, in turn, were so eager to retain jurisdiction over this powerful segment of the community that they were willing to hear and settle cases even involving Muslim contracts and instruments that contained terms in direct contradiction to rabbinic law - the

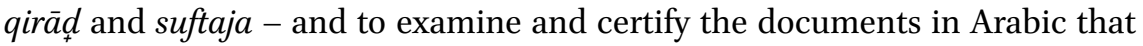
pertained to them. ${ }^{10}$ Working within the Jewish legal system, merchants were sustaining their own prestige as leaders of a dhimmi community.

Appealing to the more powerful Muslim courts, moreover, represented an escalation that was costly and risky for both parties. It necessarily imposed expenses on both sides - payments to judges, fees, and perhaps legal experts (one letter describes the difficulties of finding a Muslim legal expert, faqīh, in an ownership dispute involving Muslims, Jews, and unidentifiable 'bales')."1 The Jewish merchant's knowledge of Islamic law was almost certainly less

There is some evidence indeed that state bureaucrats helped sustain the courts' authority over the Jewish population, even sending Jewish litigants who had agreed to a settlement in the Muslim court according to Islamic formulary back to the Jewish court to make sure such proceeding was done at the behest and with the agreement of rabbinic legal authority.

$10 \quad$ See, e.g., T-S 16.138.

11 T-S 16.179 r. $47-55$. 
wide-ranging, and he was a person both juridically and practically of less importance in such a forum.

This rather long excursus into an emergent picture of the Jewish legal system within the Islamic milieu will help, I hope, explain why I also believe an explanation for the lack of lawsuits widely accepted in economic history, that proposed by Avner Greif, does not really accord with the broader evidence the Geniza offers on dispute processing.

\section{Contracts and Contract Enforcement: Economy, Society, and the State}

Greif's argument began with the assertion that the Jewish legal system was unusable and thus went unused: citing evidence both of some particularly drawn-out inheritance disputes and the failure in another case of plaintiffs to receive payment for judgments in their favor, Greif claimed the futility of legal redress. ${ }^{12}$ Greif then argued that rather than using any part of the legal system, the Jewish merchants of the Geniza instead represented a historical case of a self-enforcing system. He mapped out the theoretical possibility that a closed coalition of merchants could enforce agreements based on an internally known system of norms (provided a variety of other conditions required by the theory are met) without recourse to any external institutional framework. Rather than imagining, as Goitein had done, a long-gone heap of mercantile legal materials produced for Jewish litigants in Muslim courts, Greif's model of a self-enforcing coalition would explain the absence of lawsuits by arguing that the Geniza merchants' coalition was so effective that very little misbehavior occurred, obviating the need for lawsuits. Indeed, in a response to his critics, he pointed to the paucity of lawsuits as good prima facie evidence for his reputation-based coalition model.

I have argued elsewhere that Greif's theoretical model requires that the merchants' meet a number of criteria - including group closure, inheritance of reputation, evidence of ostracism and reprisal - for which there is little, if any evidence. I have also noted that he picks up on aspects of merchant agreements that do not fit parameters of the legal system. But in this context, Greif's work overlooks the extent to which merchants' preferences and behavior suggest that they were often eager to gain the greatest legal protections each kind of contract they entered into could offer - perhaps stronger evidence to their

12 It might be noted by legal historians that similar evidence can be produced in quantity by most functioning legal systems, including our own. 
ex ante trust in the legal system's protective capacity than incidence of lawsuits or their resolution..$^{13}$ First, they made efforts to create contracts and to adhere to Jewish forms when possible. For instance, Jewish law expected partnership contracts to be written; though the court would rule on cases involving mu'āmala (unwritten partnership contract), it would only accept written evidence of contract stipulations. ${ }^{14}$ Partnerships were very often formed to take advantage of two distant partners' positions to trade in their respective cities; the fact that they took the trouble to travel, as both principals had to be present in person, sometimes halfway across the Mediterranean, to legally secure a written contract surely shows a great devotion to legal norms. ${ }^{15}$ If merchants did not expect to rely on the legal system's protection and thus need to follow its rules, we would expect to find them exclusively using the more convenient mu'âmala, but they did so rarely. They also trusted the protections of the Muslim legal system sufficiently to enter into partnerships with Muslims, and make Muslim merchants and brokers their agents. ${ }^{16}$

Equally, in Jewish law (as in Muslim), two vital contracts, that of sale and commercial agency, are solely oral or physical (or both). ${ }^{17}$ Both could leave a paper trail: since sale and payment were separable, many sales would leave a residue of a debt in the market clerk's official records; port officials could record the ownership of arriving cargo, and into whose agency it was physically given. But of course, the primary legal evidence for such contracts would be witnessing. Indeed, merchants most show their devotion to securing legal protection for their contracts by the ubiquity of their attempts to secure legally valid testimony to their actions. Witnessing was systematic in public markets, but businessmen requested or surrounded themselves with witnesses in many other situations: valuations of unsold goods, testimony to the state of the

13 Both Greif and his critics Edwards and Ogilvie debate the meaning of both rates and success of lawsuits. But incidence of lawsuit can be read in different ways: as evidence for reliance on a legal system, as evidence for the failure of the threat of legal action to prevent cheating, as a first boundary or last resort for redress.

14 See Cambridge University Library, Oriental Collection (hereafter CUL Or) 1080J 290 for a lawsuit over a mu'āmala.

15 See, e.g. Institute of Oriental Manuscripts of the Russian Academy of Sciences, St. Petersburg (IOM).D-55.14 r. 28-29, v. 10-11.

16 A few examples: T-S 18J3.13 v. 5, T-S 8J 18.33 rt margin, Katz Center for Advanced Judaic Studies, Philadelphia (hereafter CAJS) 389 r. 30-31, v. 40, T-S 20.69, T-S 13J8.13, T-S 10J9.5, T-S 20.180, some were relationships of long duration.

17 There is also written instrument of agency, the power of attorney. The only transaction in commercial agency in which the Jewish court recognized a power of attorney might be used was in the collection of a debt - a situation in which the transfer of responsibility is not obvious. 
market for a particular commodity, opening of bales lodged in a businessman's warehouse to verify contents, and witnessing to private sales made out those warehouses. Businessmen make specific reference to such witnesses and witnessing in over a third of their letters. ${ }^{18}$ We thus find them certainly obtaining certificates attesting to transactions and quittances to completed contracts, but much more universally, making sure that their acts were witnessed. In fact, one of the most common requests we find in letters is one merchant being asked to read instructions from the sender to a third merchant, thereby making the recipient of the letter necessarily the witness, and turning written instructions into oral ones.

How, then, do I explain the low incidence of lawsuits? Well, first, there is the dodge (or reasonable hesitation, depending on your viewpoint) that Jeremy Edwards and Sheilagh Ogilvie proposed in their critique of Greif. Certainly, the incidence of lawsuits is low, but, in the absence of any comparable statistic from another merchant group, it is impossible to judge whether this particular rate of contract failure is unusually high, unusually low, or average. In this vein, I note the deformities of the evidence. First, there is the problem that the records of the rabbinic court encompass a far broader swathe of society than the correspondence of the Geniza. That is to say, the overwhelming majority of extant letters of any kind are sent among the relatively small number of the middling or upper-class individuals of this society. Though the Geniza is only beginning to reveal the degree to which different social groups in this society used literacy (though certainly people at every class used, whether willingly or not, some written documents), long-distance (or even medium-distance) correspondence tends to be the prerogative of the well-off. The records of the court capture a far wider swathe of society. As Dan Smail has discussed in his work The Consumption of Justice, many less-powerful people went to the courts in late-medieval Marseille because it offered, however imperfectly, a means of help to those without resources to get help themselves. ${ }^{19}$ Thus, the relative statistic of a much smaller percentage of merchant cases at court in comparison to the substantial percentage of letters that are mercantile is partly explained by the demography of document production. Of course, we are still in no position at all to analyze the demographics of the Jewish community, aside from being able to document Jews across a very wide range circumstances of wealth and poverty.

18 For editions and translations of quittances and releases, see Ackerman-Lieberman, Partnership Culture volume 2. On this statistic, see Goldberg publications in the bibliography.

19 Oded Zinger's thoughtful studies (see bibliography) of what kinds of Jewish women went to court in Fatimid and Ayyubid Egypt helps underscore Smail's point. 
In addition, there are some particular problems of the idiosyncratic nature of deposit practices. That is, not everyone in the Jewish community in the eleventh and twelfth centuries took geniza practice particularly seriously. Often, we find that our materials are dominated by the deposits of some key individuals who either were particularly scrupulous about geniza practice, or who left archives that an inheritor, perhaps long after their death, saw fit to deposit in the Geniza. In particular, the majority of mercantile material in the Geniza comes from the archives of just a handful of merchants (though the documents themselves make clear the existence of at least 150 identifiable Jewish merchants in the first half of the eleventh century, more than 400 in the second half, and at least 200 in the first part of the twelfth). So the disproportion between different kinds of documents may indeed be an illusion of deposit. But even with such hedging, I will still find it interesting that in a merchant community deeply aware of law, among whom some individuals were sometimes members of the court and legal experts, who took much time and effort to create a variety of legally valid documentation of their activities, and who actually talked about the possibility of legal action and legal disputes regularly in their letters, should those same merchants have so rarely ended up pursuing a lawsuit.

I suggest a few factors at work: the first one that mitigated the possibilities of dispute; the second one that shaped norms of what kinds of claims were thought court-actionable; a third that the procedure of pursuing a case helped reduce the chances of an actual lawsuit, and finally, some reasons ending up in court were more unappealing to merchants than perhaps to other kinds of litigants. Because our space is limited, and in some cases I have written far too much about these subjects, I will be somewhat summary about the first two. In framing the conundrum of the principal-agent problem in long-distance trade, economists paint a bleak theoretical problem: when a principal entrusts his goods to a distant agent, the agent can potentially use the distance to cheat (moral hazard). From shirking work to mis-reporting trades to embezzling goods, the agent can make use of delays or deficiencies in information, 'information asymmetries', to his profit. ${ }^{20}$ Several strands of evidence show, however, that merchants took for granted the capacity of Islamic institutions of ports and markets to radically reduce the length of this list, and place rather strong limits on the potential losses that contract failure could present.

20 The long-distance principal-agent problem can properly be considered part of the general problem of contract enforcement, but one in which distance magnifies the possibilities of opportunistic behavior. 
As I have already noted, market and port institutions provided both witnesses and records for some transactions and contracts. ${ }^{21}$ But equally, merchants' methods of handling a problem of transport show that they trusted Islamic institutions of the market to protect them to an unexpected degree. The infrastructure of transport (as well as maritime law) meant someone had to oversee goods on board a boat or in a caravan; equally, when purses of money or letters were transported by ship, someone needed to carry them. Such tasks required almost nothing in the way of labor for anyone already traveling; at the same time, they seem to repose an enormous degree of trust in that person. Such tasks, interestingly, were essentially performed as a free service in the general merchant community, among both Muslims and Jews. Geniza merchants relied on fellow Jewish businessmen when possible: send this with 'one of our associates', they would ask, indifferent to which one. But a Muslim businessman would do, and in a pinch, a Muslim ship's captain might carry a purse, an individual sailor look after a bale. Such actions reveal both institutions and merchant beliefs: the institutions at the ports were sufficient guarantee that persons so entrusted could not simply walk off with their goods. ${ }^{22}$ Letters suggest such trust was warranted: among a sea of troubles, no merchant ever records someone so entrusted absconding.

Indeed, both unloading of ships and major transactions were most often done in public space (ports, public markets, the warehouses of the 'agent of the merchants'), where both state officers and the local merchant community also provided substantial protection against 'information asymmetries'. Clerks recorded many transactions, payment agreements, and terms; they wrote up contracts; and they noted the state, nature, and labeling of shipments that were opened. But they were never alone: members of the Islamic merchant community witnessed these acts as well. ${ }^{23}$ The system of registration and witnessing made it possible, for instance, for one merchant in Palermo to get a

$21 \quad$ Not only was it part of the ruler's duty to uphold the 'reputation' of the market, states had their own vested interest in these transactions, which both supplied tax revenue and parts of the government's own provisioning.

22 See David Kaufmann Collection, Library of the Hungarian Academy of Sciences, Budapest (herafter DK) 231 g-k r. 22, Bodleian Library, Oxford (hereafter Bodl.) MS Heb a3.13 r. 19, CAJS 414 among many others. Muslims carrying letters: T-S 13J28.9r 7, British Library, London (hereafter BL) Or 5542.9 upper margin 1-2. Asking that a businessman entrust goods to either a Jewish or Muslim businessman: T-S 13J26.9 r. 17-18, T-S 12.133 margin. Carrying money: T-S 8J21.2 r. 3-4, a merchant instructs the recipient to send it with 'whomever you deem suitable, Muslim or Jew'. Using a ship's captain to carry money: T-S AS 145.81r 6-7. Entrusting oversight and delivery of goods to a sailor, Bodl MS Heb a3.13 v. 11.

23 For deals gone wrong that give particular good details on the presence of witnesses, see CAJS 389 r. 13-21. 39-40, 63-69, T-S 20.122 r. passim, v. 1-12. 
legal certificate on sales made by another, then send the evidence back to his associate in Alexandria (with whom he was in dispute) to prove his claim on the poor state of the market for some goods. ${ }^{24}$ Registration was important enough that even businessmen quite attentive to their dignity would fight publicity over it: 'ibn al-Wasitī came to me when I was by the clerk and he said to him: 'record that they are to the debit of al-Wasiti'. I said to him, 'Don't record them on any name except that of their owners ... and a terrible fight broke out between us in front of a group of our associates. ${ }^{25}$

States provided another prop against fraud: they set and publicized official market prices for important goods in the central markets when the bulk of a season's shipping arrived. Though actors in the market were not compelled to use the market price, sales before the market price was fixed, or that deviated too far from it, were voidable. ${ }^{26}$ Information on transactions and prices was thus a public good; letters, often in multiple copies, traveled throughout the year: 45 percent contain some market price reports (but tellingly this percentage jumps to 85 percent if we look at letters traveling in market season between ports and central markets or between the central Mediterranean and Egypt). The setting of guideline 'official prices,' and the role of merchants in multiply disseminating this information both reduced information asymmetries in fact, and created trust that reported sales could not be too wildly inaccurate despite price volatility for many goods.

Perhaps the most surprising thing to emerge from the merchant letters is a second fact, that is, merchant norms regarding payments (Greif noted this conundrum as well). Sixty days was the standard term between sale and payment, with discounts given for immediate payment upon sale. But in a legal world where delayed payments in other circumstances formed a staple of the Rabbinic court's business, among merchants, delays in payment were not considered actionable, not even considered misconduct. Even more surprising, among merchants' who exhorted their colleagues to not let capital lie idle for a

24 Bodl Ms. Heb a3.13 r. 19-21.

25 T-S 10J 10.30 r. 9-21. Another such public fight is found Jewish Theological Seminary, New York (hereafter JTS) NS 1.79. Officially, registration was not of the sale, but of the resulting payment and credit obligations - sale and payment were separate transactions, often spaced months apart; registering such arrangements at the time of sale was thus crucial. T-S 10J6.1 contains more details on how clerks registered credits and debits resulting from sales and prior debt obligations.

26 Determining market price represented a significant investment on the part of the state it involved the monitoring of shipping through a system of watchtowers (ribāts) as well as monitoring arriving goods. Market prices could only be indicative as fine distinctions of grade were made by buyers and seller. An incident in which the buyers claimed the rights to void a pre-market sale and the writer privately acknowledged it: CAJs 389 r. 63-69. 
moment, there is no record of charges for late payment. Rather, a staple of merchants' letters is the tedious work of not only reminding one's correspondent directly that payment needs to be made, but, often more importantly, asking one's colleagues to intercede with the debtor, and getting their reports back (often in the form of he asks to be reminded of the matter when he is not busy'). A not untypical example has an exasperated merchant write to his colleague who had sold goods on his behalf and not yet sent the proceeds: 'Sir, it is a small account and has been hanging fire for two years. Is it not time for it to be done? I should not have thought this of you, being sure that you were taking care of all my business. Otherwise I should not have bothered you with something tiresome, having too much esteem for you. I think that if an unknown merchant had entrusted you he would have met with better treatment than this, since I know that it is your habit and in your nature to take care of people's needs. So I (can only) conclude: This is my luck and fate and you are not to blame.'. ${ }^{27}$ Thus, in a matter for which there was legally binding evidence, merchants relied instead on exhortation, pressure, and intercession. At a practical economic level, there were many reasons such norms made sense, but it had two consequences: first, it gave many merchants on-going stakes in each other's continued solvency, and second, it could turn the getting of payment into part of merchants' on-going struggles to assert and maintain their status and reputation, their ' $j a \bar{h} h$ ', a word whose semantic field includes reputation and standing.

Merchants' sometimes protracted struggles to get paid, and the dynamics of involving other members of the community in negotiations, finally get us to the main mechanisms of dispute resolution, which in fact almost always involved ramified forms of intercession. In fact, I owe this insight into how to understand merchant dispute processing to my colleague Oded Zinger, who is in the midst of studying the place of intermediaries in access to both courts and the approach to Fatimid officials. What his work with letters across many classes and kinds of disputes reveals is that behind the legal records we have of disputes lies a stream of requests for someone who is neither party to the dispute in question, nor, interestingly, someone with official capacity to rule over it, to both hear the narrative, and then introduce it to someone who is part of the system of authority.

While in some ways such a method could be read as part and parcel of a deeply rooted patronage system, what is interesting in the case of merchants at least (whose relative statuses I am most aware of), is first, that the interceding party (or, often, parties) is not necessarily of higher status than the petitioner, 
nor always closer to the authority who might eventually be approached. Moreover, in the case of merchants, we find chains of intercession created with multiple links, not a single intermediary. Thus, in an example that shows the complexities of the process, we have a Palermo merchant 'Ațâ' b. Zikrī sitting in Alexandria, in a dispute with some other Sicilian merchants. He sends a legal query (an important step in the legal process) about the dispute. Seems simple enough as a beginning, although he sends it to Fustat, which might seem odd for a dispute among Sicilians. Not only that, he gives the query to an Egyptian merchant to carry (and no doubt read). But then he also sends a letter to another Sicilian merchant currently in Fustat. He instructs the second colleague, himself not a party to the dispute, to get the query from the first merchant (note, he could have sent the legal query enclosed in the letter but does not) and read also the enclosed account of the case and familiarize himself with the arguments. But, naturally, he is not to go directly to a legal expert but instead to 'Ațā”s colleague Nahray b. Nissīm, a merchant of Fustat who is also a legal expert. 'Ațā' notes, 'I know he does not answer legal queries, but read it to him anyway'. It is only at this stage, if no one has disapproved, that he is to go to the legal expert. He is not to give him the query, of course, but to present the case himself, 'I should like you to represent me as if I was there. Explain to him the arguments and tell him that the questioner is poor, miserable, dead, lost, and that he is presenting a (good) argument, and the (rabbi) will be assured a place in paradise'. And then, finally, 'If my master the rabbi hands down a verdict, as I said, see to it that this is witnessed by somebody whose signature is known in Sicily, (that is) if he will accept the evidence of the Sicilians in Fustat. (otherwise) have it witnessed by North Africans, by those who frequent Alexandria'. Thus, finally, do we understand that 'Ațâ' has attempted to involve a chain of five or six individuals unrelated to the case (indeed, he cautions his colleague to keep this secret from the Sicilians in town), simply in order to get a legal opinion in Fustat that might not, given the problems of witnessing, be of practical legal help when he returned to Palermo. Though we don't usually get chains this long, this practice of creating chains of intercession helps explain what used to be my favorite Geniza mystery: why one of the most important merchants of Fustat, almost always resident in the city, sent a letter from Alexandria to Fustat giving to a much less important merchant a power of attorney in order to sue his partner in a Fustat court. ${ }^{28}$

What we see in 'Ațâ"'s case is that the processes of witnessing in the marketplaces and warehouses, of getting witnesses to one's orders, actions, transfers of responsibility, valuations of goods, sales, terms of payment that might 
prevent the possibility of legal action, were balanced on the other side when disputes did arise by the gathering of adherents to one's narrative of events - a process that involved a constant testing of its efficacy and merits even as one attempted to pull more and more of the impartial community into the dispute. It was also, like the process of pressuring merchants to pay up, a marshalling of one's power of reputation and standing in the community, by attracting as many adherents as possible to one's side. In effect, then, Avner Greif had the right insight when he suggested that effectively, this made it true that it was often the merchant community, 'the people', (al-nās) that determined the merits and outcome of a dispute, as the chains of parties called upon weighed in as they were asked to intercede. Indeed, in a case Greif discusses, the same Nahray b. Nissìm who is appealed to in Fustat is told by a correspondent in Sicily that his own dispute there, and which also involved the sending of multiple streams of orders, narratives, and individuals with contrasting narratives, that the 'people' had decided some of his actions were not 'those of merchants' and that Nahray 'should be satisfied' his opponent agreed that some part of his claim would be accepted based on another merchant attesting to the arrangements described in a letter. But this suggestion was not made to Nahray because the community acted without law, but because an enormous accumulation of legal materials and legal maneuvering had already taken place.

In the larger world of the Rabbinic legal system revealed by the Cairo Geniza, lawsuits themselves follow the same logic of slow assemblage and negotiation, in which the competing narratives of the litigants are presented, but the court adjourns to acquire further legal opinions, to give litigants continual opportunities to agree to settlements, and to pressure litigants to avoid forcing the court to hand down a final judgment. ${ }^{29}$

S.D. Goitein claimed that it was a terrible blow to any merchant's reputation to go to law with an opponent. This was both true and untrue. A dignified Syrian merchant, faced with a claim that he had acted improperly, responded by saying that his business dealings were always correct, and concluded, 'I have been in business and concluded partnerships for sixty years, and never has anyone appointed an attorney against me, or brought me to court, and never have I owed a habba (1/72nd of a dinar) to anyone.... ${ }^{30}$ That is, threats of legal action and beginnings of legal action were common, but getting to the stage of actually appearing in public court, even at the stage of registering a power of attorney, represented an extreme escalation. Even the power of attorney made

29 The medieval Islamic system of litigation operated in very similar ways. See the work of David Powers (in Bibliography) on al-Wansharīsī's compendium of legal opinions. 
a case truly public. And, since a power of attorney in Rabbinic court essentially empowered one's agent to collect a debt, it immediately cast doubt on the afflicted merchant's credit-worthiness. One merchant found that after such a complaint was made against him in Fustat, everyone in his hometown of Qayarawan delayed payments to him, and another creditor in Egypt, also concerned about his solvency, also took out a power of attorney against him - and that too was seen by everyone. ${ }^{31} \mathrm{He}$ immediately attempted a settlement.

But I think we must see that with the extensive and inevitable involvement of local merchant communities in helping to create the legal validity of merchant activity and the process its disputes, for a dispute to reach the stage of a lawsuit was to be avoided because it represented a failure, not only for the plaintiff and the defendant, but for the 'people', that is, the local merchant community. For the plaintiff, it meant his jā $h$ was insufficient - insufficient to provoke compliance from his opponent, insufficient to gain him enough intercessors to pressure his opponent. It might also mean his business acumen was faulty in the first place, for having chosen the wrong partner or agent. For the defendant, not only was his probity called into question, his credit-worthiness, and hence his solvency, were often at stake. As for the local merchant community, not only had 'the people' failed to get the parties to settle, if insolvency actually ensued, they would be called upon to uphold the 'reputation' of the local market by assuring that foreign creditors were paid off before they would be able to make their own claims good. ${ }^{32}$

But we should not mistake all this maneuvering, intercession, and tendency to resolve matters before reaching a lawsuit as simply the process of peacemaking in a small-scale community that had to live together; or a way for courts to avoid giving the judgments that might also reveal their lack of executive authority to enforce their decisions; or as evidence that merchants in particular did not bother to use a legal system that was too slow, cumbersome and ineffectual for their purposes. Rather, merchant materials in particular make clear that in most cases, early points on the path to a lawsuit proved an effective end to dispute processing. Other materials help clarify that Jewish courts acted in the shadow of 'authority' (either the sulțān's men or, more ominously, just sulțān), ${ }^{33}$ not just the qadi courts, but the unnamable officials who

$31 \quad$ Bodl MS Heb a3.26, Bodl MS Heb 2.17.

32 An instance of local merchants being forced to do so is found in T-S 16.163 r. 23-28.

33 Though the English version of this word names a kind of Islamic ruler, the use of the title derives from the word for physical power or ability to impose, and thus came in the postAbbasid world to refer to someone who held supreme political but not spiritual authority, unlike a caliph, who legitimately held both. 
represented state power in its most imposing forms. And the slow, tenuous, many-step process of dispute processing, with its gathering in of many members of the community, and its many possible points to achieve resolution, must be seen against a backdrop of the ever-present threat that state power, with all its terrible speed and effectiveness, might be called in, and the nearer a case got to a lawsuit, the nearer too that threat became.

A Muslim qadi would have sufficient power, while the Jewish judge did not, to sequester goods during a lawsuit, which could help ensure the plaintiff's satisfaction, but at the same time impose financial penalties not only on the defendant, but on other members of the merchant community. Since the ownership of goods was sometimes unclear and sometimes shared, the financial hardship of such sequestration could affect many parties. In a quest to recover his property, an injured party who went to 'the authorities' thus risked permanently damaging his relationships with more colleagues than merely the defendant. Those who read the court's records tend to focus on the shame cast upon the Jewish community when its members revealed the legal problems within the community to the outside, the rhetoric of the court itself. Merchants' letters tell of more potent and individual woes: accusations of undermining Muslim institutions that left one facing the executioner's sword several times, imprisonment for non-appearance in a Muslim court (the imprisoned were required to pay the costs of their incarceration, risking torture if the guards were insufficiently paid and starvation if food were not provided), being forced to flee town, large shipments not given to one's opponent, but lost entirely in unplanned shipping. In a world of disarmed civilians, physical violations of one's person seem to have been particularly feared..$^{34}$

Calling in sulțān was not a weapon to which merchants resorted often - not only would one party have chosen retribution rather than recompense as a resolution of a dispute (no recorded instance of a Jewish merchant calling in the authorities ever resulted in getting any money back), but given the complex ownership of goods seized, and the webs of outstanding debt that (perhaps purposefully) tied merchants to one another' business, it was a weapon with often arbitrary and far-reaching consequences. And each step of the process of dispute settlement, rather than isolating the principals, pulled more and more people into cases, reminding them of their own necessary stakes in securing a peaceable and legal resolution, preferably within the bounds of their own courts' more limited and manageable authority. 


\section{Select Bibliography}

Ackerman-Lieberman, Philip I., A Partnership Culture:Jewish Economic and Social Life Seen through the Legal Documents of the Cairo Geniza (Ph.D. Dissertation Princeton University 2007).

Ackerman-Lieberman, Philip I., 'Contractual Partnerships in the Geniza and the Relationship between Islamic Law and Practice', Journal of the Economic and Social History of the Orient 54 no. 5 (2011) 646-676. https://doi.org/10.1163/156852011X614000.

Ackerman-Lieberman, Philip I., 'Legal Pluralism among the Court Records of Medieval Egypt', Bulletin d'études Orientales 63 no. 1 (2015) 79-112.

Ackerman-Lieberman, Philip I., The Business of Identity:Jews, Muslims, and Economic Life in Medieval Egypt (Stanford 2014).

Cohen, Mark R., 'A Partnership Gone Bad: Business Relationships and the Evolving Law of the Cairo Geniza Period', Journal of the Economic and Social History of the Orient 56, no. 2 (2013) 218-263. https://doi.org/10.1163/15685209-12341301.

Cohen, Mark R., 'Geniza for Islamicists, Islamic Geniza, and the "New Cairo Geniza”', Harvard Middle Eastern and Islamic Review 7 (2006) 129-145.

Cohen, Mark R., 'Jews in the Mamlūk Environment: The Crisis of 1442 (a Geniza Study)', Bulletin of the School of Oriental and African Studies 47 no. 3 (1984) 425-448.

Cohen, Mark R. and Yedida K. Stillman, 'The Cairo Geniza and the Custom of the Geniza among Oriental Jewry - A Historical and Ethnographic Study' (in Hebrew), Péamim 24 (1985) 3-35.

Crone, Patricia, God's Rule: Government and Islam (New York 2004).

Edwards, Jeremy, and Sheilagh Ogilvie, 'Contract Enforcement, Institutions and Social Capital: The Maghribi Traders Reappraised', Economic History Review 65 no. 2 (2012) 421-444.

Goitein, S.D., A Mediterranean Society; the Jewish Communities of the Arab World as Portrayed in the Documents of the Cairo Geniza. 6 vols. (Berkeley 1967).

Goitein, S.D., 'The Commercial Mail Service in Medieval Islam', Journal of the American Oriental Society 84 no. 2 (1964) 118-123.

Goitein, S.D., Letters of Medieval Jewish Traders (Princeton 1973).

Goldberg, Jessica, Trade and Institutions in the Medieval Mediterranean: The Geniza Merchants and Their Business World (Cambridge 2012).

Goldberg, Jessica, 'Choosing and Enforcing Business Relationships in the EleventhCentury Mediterranean: Reassessing the "Maghribī Traders", Past \& Present 216 no. 1 (2012) 3-40.

Goldberg, Jessica, 'The Use and Abuse of Commercial Letters from the Cairo Geniza', Journal of Medieval History 38 no. 2 (2012) 127-154.

Goldberg, Jessica, The Geographies of Trade and Traders in the Eastern Mediterranean 1000-1150: A Geniza Study (Ph.D. Dissertation Columbia University 2005). 
Goldberg, Jessica, and Eve Krakowski eds., 'Documentary Geniza Research in the Twenty-first Century: A Handbook' Jewish History 33 nos. 1-3 (2019).

Greif, Avner, 'Contract Enforceability and Economic Institutions in Early Trade - the Maghribi Traders Coalition', American Economic Review 83 no. 3 (June 1993) 525-548.

Greif, Avner, Institutions and the Path to the Modern Economy: Lessons from Medieval Trade. Political Economy of Institutions and Decisions (Cambridge 2006).

Greif, Avner, 'The Maghribi Traders: A Reappraisal?', The Economic History Review 65, no. 2 (2012) 445-469.

Greif, Avner, 'Reputation and Coalitions in Medieval Trade - Evidence on the Maghribi Traders', Journal of Economic History 49 no. 4 (December 1989) 857-882.

Hoffman, Adina and Peter Cole, Sacred Trash: The Lost and Found World of the Cairo Geniza. (New York 2010).

Jefferson, Rebecca J.W., 'Sisters of Semitics: A Fresh Appreciation of the Scholarship of Agnes Smith Lewis and Margaret Dunlop Gibson', Medieval Feminist Forum 45 no. 1 (2009) 23-49.

Jefferson, Rebecca J.W., 'The Historical Significance of the Cambridge Genizah Inventory Project' in Nachum Dershowitz and Ephraim Nissan eds., Language, Culture, Computation: Computing for the Humanities, Law, and Narratives: Essays Dedicated to Yaacov Choueka on the Occasion of His 75 Birthday (Berlin 2014) 9-37.

Krakowski, Eve, Coming of Age in Medieval Egypt: Female Adolescence, Jewish Law, and Ordinary Culture (Princeton 2017).

Lange, Christian, Justice, Punishment and the Medieval Muslim Imagination (Cambridge 2008).

Leithy, T. el-, Coptic Culture and Conversion in Medieval Cairo, 1293-1524 AD (Egypt) (Ph.D diss., Princeton University 2004).

Mottahedeh, Roy, Loyalty and Leadership in an Early Islamic Society. (London and New York 2001).

Powers, David Stephan, Law, Society, and Culture in the Maghrib, 1300-1500. Cambridge Studies in Islamic Civilization (Cambridge and New York 2002).

Rapoport, Yossef. 'Legal Diversity in the Age of Taqlád: The Four Chief Qadis Under the Mamluks', Islamic Law and Society 10 no. 2 (2003) 210-228.

Reif, Stefan C., A Jewish Archive from Old Cairo: The History of Cambridge University's Genizah Collection (Richmond, Surrey, 2000).

Rustow, Marina, 'At the Limits of Communal Autonomy: Jewish Bids for Intervention from the Mamluk State', Mamluk Studies Review 13 no. 2 (2009) 133-159.

Rustow, Marina, Heresy and the Politics of Community: The Jews of the Fatimid Caliphate. 1st edition. (Ithaca 2008).

Rustow, Marina, 'The Legal Status of Dimmīs in the Fatimid East: A View from the Palace in Cairo' in Maribel Fierro and John Tolan eds., The Legal Status of Dimmì in the 
Islamic West (Second/Eighth-Ninth/Fifteenth Centuries) (Leiden and Boston 2013) 307-332.

Smail, Daniel Lord, The Consumption of Justice: Emotions, Publicity and Legal Culture in Marseille, 1264-1423 (Ithaca 2003).

Tillier, Mathieu. 'Judicial Authority and Qāḍi s' Autonomy under the 'Abbāsids', AlMasãq 26 no. 2 (2014) 119-131.

Udovitch, A.L., 'Formalism and Informalism in the Social and Economic Institutions of the Medieval Islamic World' in Amin Banani and Speros Vryonis eds., Individualism and Conformity in Classical Islam (Wiesbaden 1977) 61-81.

Udovitch, A.L., Partnership and Profit in Medieval Islam. Princeton Studies on the Near East (Princeton 1970).

Udovitch, A.L., 'The "Law Merchant" of the Medieval Islamic World' in Gustave E. von Grunebaum ed., Logic in Classical Islamic Culture (Wiesbaden 1970) 113-130.

Zinger, Oded, 'She Aims to Harass Him': Jewish Women in Muslim Legal Venues in Medieval Egypt', AJS Review 42 no. 1 (2018) 159-192.

Zinger, Oded, Women, Gender and Law: Marital Disputes According to Documents of the Cairo Geniza (PhD Princeton University 2014). 